\title{
ARTICLE
}

\section{A Global Environmental Constitution for the Anthropocene?}

\section{Louis Kotzé*}

First published online 8 November 2018

\begin{abstract}
International environmental law (IEL) has been unable to respond effectively to the Anthropocene's global socio-ecological crisis, which is critically existential and requires radical interventions and regulatory reform. This article explores the potential of the recent United Nations (UN)-backed initiative to adopt a Global Pact for the Environment as an opportunity to reform IEL. It does so by (i) reflecting on the Anthropocene's demands for a constitutionalized form of IEL through the lens of global environmental constitutionalism; (ii) investigating the extent to which the Global Pact could contribute to such a vision; and (iii) suggesting ways in which to strengthen the constitutional potential of the Global Pact in this endeavour. To this end, the article revisits the World Charter for Nature of 1982, which seems to have slipped off the radar in academic as well as policy circles. A case is made for renewed support of the Charter - which already enjoys the backing of the majority of UN General Assembly member states, and which has constitutional qualities - to serve as a 'best-practice' example during the ensuing negotiation of the Global Pact.
\end{abstract}

Keywords: Anthropocene, International environmental law, Global environmental constitutionalism, Global Pact for the Environment, World Charter for Nature

\section{INTRODUCTION}

We are deeply immersed in a socio-ecological crisis that threatens all life on Earth. There is now convincing evidence emerging from the scientific community, ${ }^{1}$ and from

* Faculty of Law, North-West University (South Africa); University of Lincoln (United Kingdom).

Email: Louis.Kotze@nwu.ac.za.

The author wishes to thank the anonymous reviewers as well as Jordi Jaria i Manzano, Jonathan Verschuuren, Tim Stephens, Benjamin Richardson, Sam Adelman, Ole Pedersen, Joshua Gellers, Duncan French, Anna Grear, Rakhyun Kim, and Klaus Bosselmann for their comments on an earlier draft. Research for this article was supported by the author's European Commission Marie Sklodowska Curie project titled 'Global Ecological Custodianship: Innovative International Environmental Law for the Anthropocene' (GLEC-LAW) under Grant Agreement No. 751782; it was completed in July 2018.

1 See, e.g., W. Steffen et al., 'The Anthropocene: Conceptual and Historical Perspectives' (2011) 369(1938) Philosophical Transactions of the Royal Society, pp. 842-67; A. Barnosky et al., 'Approaching a State Shift in Earth's Biosphere' (2012) 486(7401) Nature, pp. 52-8. 
what we plainly observe in our daily lives, that Earth system integrity is being eroded to a point where it becomes impossible to assume the continuance of a relatively stable, resilient and harmonious Earth system as we have hitherto done in the Holocene. ${ }^{2}$ We are crossing planetary boundaries while causing a state-shift in Earth's biosphere as we are entering the Anthropocene, which is an altogether more unpredictable and unstable geological epoch. ${ }^{3}$

The socio-ecological crisis of the Anthropocene should be seen as a critically existential crisis, which requires sweeping and radical interventions at all regulatory levels. As the broader socio-ecological implications of the Anthropocene are increasingly illuminated and appreciated (if not yet fully understood) by the global scientific community, many states seem to recognize the need for global environmental law, politics and governance to more fully embrace Earth system integrity. This encouraging, if latent, realization is reflected in the formal adoption by the United Nations General Assembly (UNGA) of a 2009 resolution, which recognizes the need to live in harmony with Mother Earth, ${ }^{4}$ a recognition that is broadly reminiscent of the UNGA's similar intentions when it adopted the World Charter for Nature of 1982 (WCN), ${ }^{5}$ almost 40 years ago. Another encouraging sign is the recent initiative to negotiate and adopt the Global Pact for the Environment of 2017 (Global Pact). ${ }^{6}$

While there is little doubt that international environmental law (IEL) will continue to play an important part in humanity's efforts to navigate the Anthropocene, ${ }^{7}$ the more pertinent question that is increasingly being asked is what version of IEL should this be? Clearly the realization that we have entered the Anthropocene, alongside its apocalyptic imagery of a possible Sixth Mass Extinction caused by Anthropos, ${ }^{8}$ have far-reaching normative implications for the laws we have created to mediate the human-environment interface: 'New challenges confront environmental law. Old assumptions no longer work, and our innovations are now out of date because of the pervasive change that the Anthropocene represents'. ${ }^{9}$ However, these implications are as yet under-explored. As Stephens says, 'most accounts of international environmental law have yet to come to grips with the immense consequences that the Anthropocene

2 Or the 'entirely recent' geological epoch.

3 P. Crutzen \& E. Stoermer, "The "Anthropocene" (2000) 41 IGBP Global Change Newsletter, pp. $17-8$.

4 UNGA Resolution 64/196 (21 Dec. 2009), 'Harmony with Nature', UN Doc. No. A/RES/64/196. For other resolutions related to the UN Harmony with Nature initiative see: http://www.harmonywithnatureun.org/unDocs.

5 UNGA Resolution $37 / 7$ (28 Oct. 1982), 'World Charter for Nature', UN Doc. No. A/RES/37/7, available at: http://www.un.org/documents/ga/res/37/a37r007.htm.

6 Global Pact for the Environment, Paris (France), 24 June 2017, available at: http://pactenvironment. emediaweb.fr/wp-content/uploads/2017/07/Global-Pact-for-the-Environment-project-24-June-2017.pdf.

7 F. Biermann et al., 'Navigating the Anthropocene: Improving Earth System Governance' (2012) 335(6074) Science, pp. 1306-7.

8 A. Barnosky et al., 'Has the Earth's Sixth Mass Extinction Already Arrived?' (2001) 471(7336) Nature, pp. 51-7.

9 N. Robinson, 'Fundamental Principles of Law for the Anthropocene?' (2014) 44(1/2) Environmental Policy and Law, pp. 13-27, at 13. 
poses for global environmental governance, ${ }^{10}$ a fact that is also clearly reflected in the relative paucity of scholarship on the role of IEL in the Anthropocene. ${ }^{11}$

Within the inchoate body of law and Anthropocene critique, commentators do seem to agree that IEL has been unable to sufficiently and effectively respond to the Anthropocene's global socio-ecological crisis. ${ }^{12}$ That we are now being confronted by Anthropocene phenomena is in itself suggestive evidence of the failures of IEL in this respect. IEL has contributed to causing, and still sometimes actively perpetuates, Anthropocene-inducing events that are pushing humanity across planetary boundaries. ${ }^{13}$ If we are to respond more effectively to the growing socio-ecological crisis of the Anthropocene, then IEL clearly will need to be reformed along new and alternative lines. Such reforms must be radical and globally all-encompassing. They must reach deep into the very fabric and core normative foundations of IEL and, ultimately, of state actions and of society itself. ${ }^{14}$

One possibility through which to accomplish such deep reforms could lie in the global environmental constitutionalism paradigm which focuses on the manifestation of constitutional law, ideas, concepts and processes in global environmental law and governance. ${ }^{15}$ While global environmental constitutionalism is an increasingly popular topic of research, ${ }^{16}$ little attention has been paid to the issue of whether a global environmental constitution exists or should exist as part of IEL. Approximately coinciding with debates that focused on the need to establish a powerful international environmental organization within United Nations (UN) structures, ${ }^{17}$ but well before the Anthropocene's imagery started to permeate legal studies, Bodansky asked: 'Is there an international environmental constitution?' ${ }^{18} \mathrm{He}$ ultimately concluded that such a constitution, in the fullest sense of the word, does not exist, despite several instruments that have been proposed to serve this purpose. ${ }^{19}$

10 T. Stephens, 'Reimagining International Environmental Law in the Anthropocene', in L. Kotzé (ed.), Environmental Law and Governance for the Anthropocene (Hart, 2017), pp. 31-54, at 32.

11 Apart from the few scientific articles and book chapters referenced throughout this article, no comprehensive treatise (yet) exists on the normative implications of the Anthropocene for IEL, although researchers are now starting to focus on this issue: see, e.g., Tim Stephens' project at the University of Sydney (Australia), International Law and the Anthropocene (Australian Research Council, Future Fellowship).

12 See generally Kotzé, n. 10 above.

13 R. Kim \& K. Bosselmann, 'International Environmental Law in the Anthropocene: Towards a Purposive System of Multilateral Environmental Agreements' (2013) 2(2) Transnational Environmental Law, pp. 285-309.

14 L. Kotzé, 'Rethinking Global Environmental Law and Governance in the Anthropocene' (2014) 32(2) Journal of Energy and Natural Resources Law, pp. 121-56.

15 L. Kotzé, Global Environmental Constitutionalism in the Anthropocene (Hart, 2016).

16 B. Gareau, 'Global Environmental Constitutionalism' (2013) 40(2) Boston College Environmental Affairs Law Review, pp. 403-8, at 408 (calling global environmental constitutionalism 'a breath of fresh air').

17 F. Biermann \& S. Bauer (eds), A World Environment Organization: Solution or Threat for Effective International Environmental Governance? (Ashgate, 2005).

18 D. Bodansky, 'Is There an International Environmental Constitution?' (2009) 16(2) Indiana Journal of Global Legal Studies, pp. 565-84.

19 Including, among others, Agenda 21 (UN Conference on Environment and Development, Rio de Janeiro (Brazil), 3-14 June 1992, available at: https://sustainabledevelopment.un.org/content/documents/Agenda21.pdf), the Stockholm Declaration on the Human Environment of 1972 (n. 73 below), 
Today, almost a decade later - and with the benefit of viewing this issue anew through the analytical lens of the Anthropocene and a more fully developed theory of global environmental constitutionalism ${ }^{20}$ - I wish to revisit Bodansky's question while capitalizing on the momentum created by the negotiation of the Global Pact, which itself has the potential to become a global environmental constitution.

The Global Pact is being driven by France, ${ }^{21}$ and its negotiation commenced in May 2018 following a formal UNGA resolution (143 votes in favour, 6 against, 6 abstentions). ${ }^{22}$ Signalling the underlying global constitutional intentions of its drafters, the Pact's objectives seem to be three-pronged: (i) to be a globally binding environmental law instrument; (ii) to thus entrench all major principles of IEL in one document; while also (iii) developing progressively the law to provide a globally recognized right to live in an ecologically sound environment, with associated procedural environmental rights. Especially with regard to the latter objective, the aim eventually is to present the Pact to the UNGA for adoption so that it could represent the 'third generation of [environmental] rights' alongside the International Covenant on Civil and Political Rights (ICCPR) and the International Covenant on Economic Social and Cultural Rights (ICESCR) of $1966 .{ }^{23}$ Yet, a plain reading of the text suggests that, with a few exceptions, the Pact disappointingly regurgitates generally accepted principles of IEL in much the same way that all previous global environmental declarations and soft law instruments have done. More worryingly, it is devoid of an ecocentric ethic of socio-ecological care, and insufficiently focused on maintaining Earth system integrity. It therefore does not represent anything dramatically different from that which already exists, and its potential as a global environmental constitution for the Anthropocene is decidedly muted.

In an effort to make a constructive contribution to the dialogue about the purpose, content and future development of the Global Pact, I also revisit the WCN, which I argue could be used as an example of what should and could be achieved by the Global Pact. The Charter has received scant attention from commentators and, where it has, analysis is usually cursory, with the Charter mostly relegated to the realm of

the Rio Declaration on Environment and Development of 1992 (n. 73 below), the World Conservation Union (IUCN) Draft Covenant of 2010 (available at: https://portals.iucn.org/library/sites/library/files/ documents/EPLP-031-rev3.pdf), and the Earth Charter (Paris (France), 2000, available at: http://earthcharter.org/virtual-library2/the-earth-charter-text): K. Bosselmann, 'Global Environmental Constitutionalism: Mapping the Terrain’ (2015) 21(2) Widener Law Review, pp. 171-85.

20 Kotzé, n. 15 above.

21 IUCN, 'Global Pact for the Environment Introduced to the World', 23-24 June 2017, available at: https:/www.iucn.org/commissions/world-commission-environmental-law/events/23-24-june-2017-global-pact-environment-introduced-world.

22 UNGA Resolution 72/277 (10 May 2018), 'Towards a Global Pact for the Environment', UN Doc. No. A/RES/72/277. The states voting against were Iran, Philippines, Russian Federation, Syria, Turkey, and the United States (US); while the states abstaining were Belarus, Malaysia, Nicaragua, Nigeria, Saudi Arabia, and Tajikistan.

23 ICCPR, New York (USA), 16 Dec. 1966, in force 23 Mar. 1976, available at: https://www.ohchr.org/ Documents/ProfessionalInterest/ccpr.pdf; ICESCR, New York (USA), 16 Dec. 1966, in force 3 Jan. 1976, available at: https://www.ohchr.org/en/professionalinterest/pages/cescr.aspx. See also IUCN, n. 21 above. 
potential soft law. ${ }^{24}$ Curiously, the WCN also seems to have slipped off the radar of state concern. Beyond its initial proclamation, it has not featured prominently in or exerted any significant norm-shaping influence on the development of IEL. Instead, all major global environmental conferences since the 1990 s pointedly retreated from the deep ecological principles of the WCN. ${ }^{25}$ This is surprising and disappointing, especially considering that the WCN has been endorsed by the majority of UNGA member states. For reasons I explore later in detail, the Charter could arguably play a pivotal role as part of a 'body of precedent-setting law and practice [that] has begun to take on the character of an international constitution for the world environment', ${ }^{26}$ to the extent that it could serve as a 'best practice' example for states and other stakeholders involved when drafting the Global Pact.

The discussion is structured as follows. For the purpose of context, Part 2 immediately below focuses on the state of IEL in the Anthropocene, including its many regulatory failures and few achievements. This discussion supports an argument in favour of the adoption of a global environmental constitution. Accordingly, Part 3 investigates the notion of global environmental constitutionalism. Part 4 interrogates the extent to which it could be said that a global environmental constitution already exists. It then analyzes the Global Pact in its present form, followed by an interrogation of the WCN in an effort to juxtapose the two texts, while proposing ways forward in which the content of the Global Pact might be shaped to correspond more fully with that of the Charter.

\section{INTERNATIONAL ENVIRONMENTAL LAW AND THE ANTHROPOCENE}

As the primary collection of global norms responsible for steering the world on the path to 'sustainable development', ${ }^{27}$ IEL - which since its inception has taken for granted the relatively stable Holocene conditions - is acutely implicated by the normative consequences of the Anthropocene. ${ }^{28}$ Admittedly, it would be both incorrect and unfair to pin the existence of the Anthropocene exclusively on the perceived failures of IEL. After all, as Verschuuren notes, 'the events that led to the Anthropocene have already existed well before the adoption of most of the principles [of IEL]' ${ }^{29}$ What is nevertheless clear is that the failures of IEL, along with the failures of many other

24 See, e.g., P. Dupuy \& J. Viñuales, International Environmental Law (Cambridge University Press, 2015), pp. 34-5.

25 B. Devall, 'The Deep, Long-Range Ecology Movement: 1960-2000: A Review' (2001) 6(1) Ethics and the Environment, pp. 18-41, at 30.

26 L. Caldwell \& P. Weiland, International Environmental Policy: From the Twentieth to the TwentyFirst Century, $3^{\text {rd }}$ edn (Duke University Press, 1996), p. 354.

27 A goal which itself has been subject to criticism because of its anthropocentric ontology: see S. Adelman, 'The Sustainable Development Goals, Anthropocentrism and Neoliberalism', in D. French $\&$ L. Kotzé (eds), Sustainable Development Global Goals: Law, Theory and Implementation (Edward Elgar, 2018), pp. 15-40.

28 D. Vidas et al., 'International Law for the Anthropocene? Shifting Perspectives in Regulation of the Oceans, Environment and Genetic Resources' (2015) 9 Anthropocene, pp. 1-13, at 4.

29 J. Verschuuren, 'The Role of Sustainable Development and the Associated Principles of Environmental Law and Governance in the Anthropocene', in Kotzé, n. 10 above, pp. 3-29, at 4. 
neoliberal regulatory institutions such as economics, have not enabled humanity during the past century to sufficiently mitigate harmful socio-ecological practices, to sufficiently adapt to global socio-ecological change, and to build resilient and peaceful societies that respect Earth system limits and Earth system integrity:

If anything, there seems to be a deepening of neoliberal capitalist ideology's grip on mainstream international strategies for addressing the eco-crisis, and much of Western law and culture - which includes international law as an extension of Western commitments and power - seems committed to maintaining 'business as usual' - a reductive set of capitalist globalised practices directly linked to climate destruction. ${ }^{30}$

While the central overarching purpose of IEL ideally should be the achievement of socio-ecological integrity and respect for planetary boundaries, as Kim and Bosselmann convincingly argue, ${ }^{31}$ IEL has not managed to achieve this lofty goal. Instead, international environmental law has matured quickly and accomplished some significant things. It has shown signs of premature aging and must change its habits, lest it suffer a premature death, just when we need it most'. ${ }^{32}$

Focusing specifically on a range of multilateral environmental agreements (MEAs) that he discusses in context with the various planetary boundaries, in a recent analysis Stephens evaluates the performance of IEL in terms of the ability of its treaty regimes to maintain a 'safe operating space' where planetary boundaries are not being crossed. ${ }^{33} \mathrm{He}$ concludes that IEL has been unable to keep humanity from crossing or fast approaching planetary boundaries, because in the main it is not always based on proper science; it often lacks specific quantifiable objectives and clear ways to reach these; its consensual nature is inherently problematic; its normative and institutional fragmentation and piecemeal focus do not take into account the reciprocally interlinked nature of the Earth system; and it is fraught with politics and confronted by the same problem of exceptionalism that bedevils other areas of global law and politics. Relatedly, the success of IEL depends on state consent and support, which is not always forthcoming; some areas remain unregulated (such as atmospheric aerosol loading and freshwater resources); and diplomatic and norm-creation fatigue are the order of the day, with IEL seemingly being in a state of limbo. IEL also grants too much latitude to state sovereignty while ineffectively sanctioning states' non-compliance with their legal obligations. ${ }^{34}$ A central concern here is that supervising the implementation of MEAs does not generally extend to coercive action against states, ${ }^{35}$ which is surprising if one considers that coercive action is often used against states in other critical areas such as human rights transgressions.

30 A. Grear, 'Towards a New Horizon: In Search of a Renewing Socio-Juridical Imaginary' (2013) 3(5) Oñati Socio-Legal Series, pp. 966-90, at 970 (emphasis in original).

31 Kim \& Bosselmann, n. 13 above.

32 D. Driesen, 'Thirty Years of International Environmental Law: A Retrospective and Plea for Reinvigoration' (2003) 30 Syracuse Journal of International Law and Commerce, pp. 353-68, at 368.

33 Stephens, n. 10 above, pp. 34-47.

34 L. Kotzé, 'Arguing Global Environmental Constitutionalism' (2012) 1(1) Transnational Environmental Law, pp. 199-233, at 202.

35 A. Kiss, 'The Legal Ordering of Environmental Protection', in R. St. John Macdonald \& D. Johnston (eds), Towards World Constitutionalism: Issues in the Legal Ordering of the World Community (Martinus Nijhoff, 2005), pp. 567-84, at 575. 
The ineffectiveness of IEL is supposedly not the result of a lack of norms that formally establish and regulate global environmental governance. ${ }^{36}$ However, the impressive growth of IEL over the years has followed a path-dependent growth trajectory, which has seen a continuation of new lawmaking practices based on historic use with little meaningful change to the ethical orientation, depth, scope, level of care, and objectives of most of its main instruments. Raustiala argues that because new international rules and institutions are rarely negotiated on a clean slate, the choice of new rules is limited by the existing constellation of rules and the political interests these rules have engendered: 'As international rules and institutions multiply, this normative legacy, or overhang, grows. Sometimes the result of this variegated normative legacy is statis [sic]'. ${ }^{37}$ The IEL-making process is now seemingly halted for the moment and in a state of stasis, with the focus shifting to the consolidation and extension of existing regimes rather than rapid legal development. ${ }^{38}$ This allows for an opportunity to refocus attention on concerns about the ineffectiveness of IEL, which increasingly centres on the alleged absence of socio-ecological ethics and peremptory ecological obligations within its normative content, and a lack of perceived binding authority of its norms and obligations. There is a concern that IEL is an authority that is often easily trumped by the self-interested political, neoliberaldriven whims of states and the corporations that undergird their economic prosperity.

For example, it is clear from some of the core terminology adopted by IEL including 'environmental resources', 'ecosystem services', 'green economy', and perhaps most notoriously 'sustainable development' ${ }^{39}$ - that IEL is predominantly based on a green-washed neoliberal anthropocentric ethic, devoid of a deeper sense of ecological obligation. IEL derives from a growth-without-limits imperative and a 'continuing commitment to eco-destructive capitalist commitments ${ }^{40}$ that are successfully facilitated by ideological palliatives such as sustainable development, ${ }^{41}$ rendering its norms and institutions unable to respond meaningfully to the Anthropocene. IEL is also devoid of a core set of fundamental values that binds states and it does not provide unitary requirements with regard to norm creation and institutional operation: the current set of soft law principles shared by many IEL instruments does not 'represent a core value system for the international community a set of fundamental, substantive rules that might be analogized to a constitution'. ${ }^{2}$

36 Kim \& Bosselmann, n. 13 above, pp. 285-6.

37 K. Raustiala, 'Density and Conflict in International Intellectual Property Law' (2007) 4 University of California Davis Law Review, pp. 1021-38, at 1026.

38 P. Sands \& J. Peel, Principles of International Environmental Law, 3rd edn (Cambridge University Press, 2012), p. 891.

39 M. Redclift, 'Sustainable Development (1987-2005): An Oxymoron Comes of Age' (2005) 13 Sustainable Development, pp. 212-27 (emphasis added).

40 Grear, n. 30 above, p. 970.

41 B. Richardson, 'A Damp Squib: Environmental Law from a Human Evolutionary Perspective' (2011) 7(3) Osgoode Hall Law School Comparative in Law and Political Economy Research Paper Series, pp. $1-42$, at 31 .

42 Bodansky, n. 18 above, pp. 579-80. 
Some of these concerns have motivated the drafting of the Global Pact, as we shall see below.

If we agree with Dalby that 'the future configuration of the Earth System is now the key matter of geopolitics, of how the world is known, reorganized and rebuilt in the struggles for economic and political mastery in rapidly changing circumstances', ${ }^{43}$ then it requires little argument to support initiatives aimed at addressing the aforementioned deficiencies of IEL through efforts to radically reform this body of global law so that it would be better able to keep the Earth system in a safe operating space. Inquiries into ways to improve the effectiveness of IEL are almost as old as this body of norms itself, ranging from 'softer' proposals to address fragmentation, to make it more coherent and to enhance its scope, and proposals to encourage the adoption of MEAs by states or the development and utilization of soft law instruments, ${ }^{44}$ to more deliberately thorough, transformative and far-reaching reform actions. The latter include, for example, proposals to establish a world environment organization much more powerful than the current UN Environment, the consolidation of MEAs under this institution, ${ }^{45}$ the creation of a global environmental court and an ombudsman for future generations, and the reform of the UN Trusteeship Council into the UN Environment Trusteeship Council - none of which to date have materialized. ${ }^{46}$

More recent proposals are noticeably motivated by the Anthropocene trope, which evokes a profound image of crisis and instability that is neither insignificant nor unimportant from a normative point of view. ${ }^{47}$ The crisis of the Anthropocene is also a crisis for IEL as it goes to the heart of questions and conversations relating to the objectives, scope, ontology, purpose, legitimacy, and effectiveness of IEL. At the same time, the advent of the Anthropocene has considerable potential to re-ignite and steer reform conversations in more innovative, creative and potentially far-reaching ways that can transcend the pervasive and destructive state self-interests prevailing in global environmental law, governance and politics. After all, in the Anthropocene, 'prioritizing existence over self-interest [in the face of cataclysmic disasters] enjoys wide, if tacit, acceptance'. ${ }^{48}$ To this end, commentators argue for a more coherent body of IEL norms that is based on a unifying constitution-type Grundnorm such as

43 S. Dalby, 'Framing the Anthropocene: The Good, the Bad and the Ugly' (2015) 3(1) The Anthropocene Review, pp. 33-51, at 34.

44 Sands \& Peel, n. 38 above, pp. 888-97.

45 S. Oberthür \& T. Gehring, 'Reforming International Environmental Governance: An Institutionalist Critique of the Proposal for a World Environment Organisation' (2004) 4(4) International Environmental Agreements: Politics, Law and Economics, pp. 359-81.

46 O. Pedersen, 'An International Environmental Court and International Legalism' (2012) 24(3) Journal of Environmental Law, pp. 547-58; N. Kanie et al., 'A Charter Moment: Restructuring Governance for Sustainability' (2012) 32(3) Public Administration and Development, pp. 292-304, at 293.

47 It is argued that '[s]tability is deeply embedded in the fundamentals of international law, where it operates at two levels. One is the conscious objective of working towards legally guaranteed stability in international relations, in turn prone to frequent political change. The other level of stability is implied: it is the assumption, based on our experience so far, of constantly stable circumstances of the late Holocene. Many aspects of international law are based on such understanding of the stability of the Earth conditions': Vidas et al., n. 28 above, p. 4.

48 S. Jasanoff, 'A World of Experts: Science and Global Environmental Constitutionalism' (2013) 40(2) Boston College Environmental Affairs Law Review, pp. 439-52, at 444. 
ecological integrity, which could be embedded in a global environmental constitution. $^{49}$ The hypothesis is that a constitutionalized form of IEL, which prioritizes Earth system integrity and care, could potentially better respond to the type of challenge that Sands and Peel present to us in the final paragraph of their seminal treatise on IEL: 'This is not a time for complacency, or celebration of achievement. Quite the contrary' ${ }^{50}$

In order to address these concerns, the reforms that will be required of IEL clearly must be on a scale and at a level and depth never seen before. They must at least be akin to the global law and governance reforms following the Second World War, a period in history which arguably represents the last major 'global constitutional moment'. In fact, there is a strong argument to be made in support of the Anthropocene representing an imminent global constitutional moment, ${ }^{51}$ during which sweeping IEL reforms will have to occur, including reforms of its core assumptions, objectives, ontology, and design:

The world saw a major transformative shift in governance after 1945 that led to the establishment of the UN and numerous other international organizations, along with farreaching new international legal norms on human rights and economic cooperation. We need similar changes today, a 'constitutional moment' in world politics and global governance. $^{52}$

The creation of a global environmental constitution is likely to be a critical part of such reforms during the course of the Anthropocene's global constitutional moment, very much in the same way that the Charter of the United Nations - to date the only more or less generally accepted global constitution - created a new world order in 1945. ${ }^{53}$ The following part critically reflects on the meaning and core aspects of global environmental constitutionalism.

\section{GLOBAL ENVIRONMENTAL CONSTITUTIONALISM}

While global constitutionalism can have several context-specific meanings, and the literature on this topic is truly overwhelming, Peters offers a concise description that is useful for present purposes:

The claim of probably all types of global constitutionalism is that the respective principles, institutions, and mechanisms [of domestic constitutionalism] can and should be used as parameters to inspire strategies for the improvement of the legitimacy of an international legal order and institutions without asking for a world state. ${ }^{54}$

49 Kim \& Bosselmann, n. 13 above.

50 Sands \& Peel, n. 38 above, p. 897.

51 L. Kotzé, 'The Anthropocene's Global Environmental Constitutional Moment' (2015) 25(1) Yearbook of International Environmental Law, pp. 24-60.

52 Biermann et al., n. 7 above, p. 1307.

53 New York (USA), 26 June 1945, in force 24 Oct. 1945, available at: https://treaties.un.org/doc/publication/ctc/uncharter.pdf. See, among others, M. Doyle, 'Dialectics of a Global Constitution: The Struggle over the UN Charter' (2011) 18(4) European Journal of International Relations, pp. 601-24.

54 A. Peters, 'Global Constitutionalism', in M. Gibbons (ed.), The Encyclopedia of Political Thought (John Wiley and Sons, 2015), pp. 1484-7, at 1484. 
To this end, global constitutionalism is usually employed as a strategy seeking to address the regulatory problematique of the global law and governance order. Some of the key issues that global constitutionalism addresses include:

- the normative and political aspects related to state sovereignty;

- lack of legitimacy and authority of international laws, governance actors and processes;

- the rise of global non-state actors, such as transnational corporations operating outside juridical boundaries of accountability;

- the intensification of globalized processes, such as trade and migration; and

- the rise of complex global governance challenges, such as terrorism, migration and environmental degradation, and their normative implications. ${ }^{55}$

The global constitutionalism debate essentially commenced with academic critique and reconstruction of the founding treaties of international organizations, including the UN and its Charter, the European Union and the World Trade Organization. The debate signified 'an evolution from an international order based on some organizing principles, such as state sovereignty and consensualism, to an international legal order which acknowledges and has creatively appropriated principles and values of constitutionalism'. ${ }^{56}$ Perhaps most clearly, the roots of global constitutionalism are located in debates concerning the place of human rights in international law, including the question whether a normative constitutional hierarchy exists in international law. ${ }^{57}$ What all the foregoing have in common is their reflection on the ideas that the juridification of international relations should be governed by legal rules instead of merely by state power and interests. The legitimacy of international law should not depend solely on state consent, but also on considerations such as limited and efficient government, the separation of powers, the rule of law, democracy, and the protection of human rights. ${ }^{58}$ This would imply, among other things, that while states are the subjects of a global constitutional order, they are at once (or at least should be) entirely subjected to binding and constraining international 'constitutional' rules that are supported by the majority of states and people within states.

To what extent does this vision of global constitutionalism manifest in the global environmental regulatory domain? As a point of departure, one must first acknowledge the critical need for situating the Anthropocene's socio-ecological crisis within the broader narrative and parameters of global constitutionalism. Bosselmann says:

55 R. St. John Macdonald \& D. Johnston, 'Introduction', in St. John Macdonald \& Johnston, n. 35 above, pp. ix-xviii.

56 Peters, n. 54 above, p. 1485.

57 O. Diggelmann \& T. Altwicker, 'Is there Something like a Constitution of International Law? A Critical Analysis of the Debate on World Constitutionalism' (2008) 68 Zeitschrift für ausländisches öffentliches Recht und Völkerrecht, pp. 623-50, at 625-8.

58 E. de Wet, 'The International Constitutional Order' (2006) 55(1) International and Comparative Law Quarterly, pp. 51-76, at 52-3. 
Both the protection of human rights and the protection of the environment are constitutionally relevant precisely because of their fundamental importance. Environmental protection has constitutional status in most, although not all, states. If we accept that the twenty-first century will be defined by its success or failure of protecting human rights and the environment, then global environmental constitutionalism, like global constitutionalism in general, becomes a matter of great urgency. ${ }^{59}$

The broad description of global constitutionalism offered above, when extrapolated to the environmental domain, would mean that global environmental constitutionalism offers an opportunity to interrogate and to ameliorate some of the challenges confronting IEL and its associated global environmental governance regime by applying constitutional principles, institutions and mechanisms to guide strategies for the improvement of IEL and to confront, head on, its myriad deficiencies and failures. This would include not only the deficiencies and failures particular to IEL discussed in Part 2, but also the general regulatory challenges that global constitutionalism seeks to address in the environmental domain. Such challenges include:

- the prohibitive effect of state sovereignty and exceptionalism as far as compliance with MEA obligations is concerned;

- the legitimacy and efficacy of IEL;

- the impact of globalization on IEL and global environmental governance, which necessitates a search for more effective strategies to address the diverse harmful environmental impacts resulting from globalization;

- the binding authority of IEL; and

- ways to increase and/or extend liability for environmental harm to non-state actors.

Does a global environmental constitution already exist? At best it could be said that the current body of MEAs makes up some sort of weak or 'thin' global environmental constitution at the 'lowest level', best described as a constitution 'with a little "c" rather than a big "C"':

Rather than elaborate a set of static commitments by states, [MEAs] are dynamic arrangements that establish ongoing systems of governance to address particular issues ... Although they differ in their particulars, each international environmental agreement performs basic constitutive functions by establishing institutions, specifying the rules that guide and constrain these institutions, and entrenching these rules through amendment procedures. ${ }^{60}$

While it formally constitutes and regulates global environmental governance, the current MEA regime does very little to provide for higher order, substantive or 'thicker' norms (such as those expressed through human rights in domestic constitutions). More particularly, this regime does not offer norms that fully represent the law of an emerging international community with shared environmental

59 Bosselmann, n. 19 above, p. 173.

60 Bodansky, n. 18 above, pp. 578, 574. 
responsibilities, solidarity and values; norms that have a higher status independent from state consent; or norms that represent a unified, comprehensive system that must ensure a high level of environmental protection. ${ }^{61}$ Perhaps more critically, the MEA regime is neither based on nor provides for a Grundnorm-type ecocentric ethic of ecological care, which is a sine qua non if IEL is to more effectively safeguard global ecological integrity by moving away from its deeply pervasive anthropocentric ontology that exacerbates Anthropocene events. ${ }^{62}$

The more pertinent (and admittedly difficult) question I therefore wish to focus on is this: could it be said that any measure of substantively 'thick' global environmental constitutionalism already exists that includes, among other matters, 'environmental values, principles, and rights that are sufficiently coherent and enduring to form a [global environmental] constitution'? ${ }^{63}$ None of the three instruments collectively known as the International Bill of Rights (i.e., the Universal Declaration of Human Rights of 1948 (UDHR), ${ }^{64}$ the ICCPR and the ICESCR) provides for a right to a healthy environment. Moreover, as of yet, there are no peremptory jus cogens norms situated at the top of international law's normative hierarchy that explicitly relate to the environment by, for example, prohibiting severe and widespread pollution. There are also no norms that prohibit states from transgressing a minimum threshold of sustainability; or norms that prohibit states from changing the climate through greenhouse gas emissions. ${ }^{65}$ It is accordingly at present impossible to conclude that environmental concerns are represented in any meaningful way in the broader 'international value system [which] concerns norms with a strong ethical underpinning, [and] which ... have acquired a special hierarchical standing through State practice'. ${ }^{66}$ It is also clear that within the domain of IEL 'states still prefer to retain significant flexibility rather than commit to constitutional constraints. They remain far from developing the sense of community that underlies constitutional governance [at the global level]' ${ }^{67}$

If global constitutionalism developed as a response to the challenges confronted by international law, clearly it will also have a meaningful role to play with respect to addressing some of the challenges and deficiencies of IEL. This could occur through formal global constitutional reforms that aim to improve the institutional and procedural governance structures of IEL. More importantly for present purposes, it could happen through the creation of universally binding constitution-type norms that restrict the environmentally harmful actions of states and impose on them an ecocentric ethic of care obligation with respect to Earth system integrity. In anticipation, the discussion in the following part suggests that the next logical step

61 Ibid., p. 575.

62 Kim \& Bosselmann, n. 13 above.

63 Bosselmann, n. 19 above, p. 176.

64 Paris (France), 10 Dec. 1948, UNGA Resolution 217A, UN Doc. A/810, available at: http://www.un. org/en/universal-declaration-human-rights.

65 L. Kotzé, 'Constitutional Conversations in the Anthropocene: In Search of Environmental Jus Cogens Norms' (2015) 46 Netherlands Yearbook of International Law, pp. 241-71.

66 De Wet, n. 58 above, p. 57.

67 Bodansky, n. 18 above, p. 584. 
would be the adoption of a global environmental constitution which entrenches binding, higher order constitutional environmental law norms in response to the Anthropocene's global constitutional moment.

\section{A GLOBAL ENVIRONMENTAL CONSTITUTION}

As is the case for global constitutionalism generally, thinking about IEL in constitutional terms beyond the axiomatic boundaries of the state, and beyond the boundaries of state-based constitutional law, requires some epistemological flexibility and creativity. As Diggelmann and Altwicker say, in the past 'endorsing [global constitutionalism] was considered a somewhat extravagant position - associated with delusional, rather than progressive thinking' ${ }^{68}$ Jasanoff's view seems the more appropriate counterpoint in the light of the creative epistemic and far-reaching normative demands of the Anthropocene:

Rigid legalistic thinking ... can undermine the processes of global agenda-setting ... In a time of mounting concern about our threatened future, it is well to remember that the institutions we have built are meant to serve us, and not forget that neither scientific nor legal expertise sits beyond questioning or beyond reform. ${ }^{69}$

\subsection{The Global Pact for the Environment}

The intention behind the Global Pact seemingly is for it to break free from the confines of 'rigid legalistic thinking' and, in the process, to perhaps become a global environmental constitution. The Global Pact clearly signposts its global constitutional ambitions because it provides an explicit right to live in an ecologically sound environment. ${ }^{70}$ It is anticipated that the Global Pact will represent the 'third generation of [environmental] rights, ${ }^{71}$ and be 'to the Rio Declaration what the 1966 International Covenants [ICCPR and ICESCR] are to the 1948 Universal Declaration of Human Rights'. ${ }^{72}$ Moreover, the Global Pact is not intended to be a 'mere' nonbinding declaration similar to the Stockholm or Rio Declarations; ${ }^{73}$ which is possibly a deliberate attempt by its drafters to raise expectations, to influence perceptions about its intended normative force, and to avoid from the outset the pitfalls of soft normativity associated with soft law declarations. A principal motivation behind drafting the Pact is to offer a binding international treaty establishing the fundamental principles of environmental law' as a response to the 'strong

68 Diggelmann \& Altwicker, n. 57 above, p. 623.

69 Jasanoff, n. 48 above, p. 452.

70 Global Pact, n. 6 above, Art. 1.

71 IUCN, n. 21 above.

72 Le Club de Juristes, White Paper: Toward a Global Pact for the Environment (Le Club de Juristes, 2017), p. 32.

73 Declaration of the United Nations Conference on the Human Environment, UN Doc. A/Conf.48/14/ Rev. 1 (1973), 16 June 1972, available at: http://www.un-documents.net/aconf48-14r1.pdf; Rio Declaration on Environment and Development, adopted by the UN Conference on Environment and Development, Rio de Janeiro (Brazil), 3-14 June 1992, UN Doc. A/CONF.151/26/Rev.1 (Vol. I), available at: http://www.un.org/documents/ga/conf151/aconf15126-1annex1.htm. 
expectation from the legal community to see the foundations of environmental regulation systematised in a single instrument at an international level'. ${ }^{74}$ As a binding instrument, the Pact endeavours to 'strengthen the coherence of global governance of the environment' and to eventually become 'the cornerstone of international environmental law, with the sectoral conventions being the mode of implementation for specific areas of the general principles of the Pact'. ${ }^{75}$ To this end, the Global Pact is presumably expected to fulfil the typical role of constitutions namely, to act as an overarching framework setting forth general binding provisions, while the sector-based details are provided in subsequent instruments such as MEAs.

Further, in pursuit of its global constitutional ambitions, this instrument is fashioned around the francophone idea of a pact: an agreement espoused as a solemn promise without reservation among like-minded states that share common concerns whereby they purposively commit to undertake specific actions to achieve a certain objective for their mutual benefit. I would suggest the word 'pact' is a deliberate designation, and is reminiscent of related terms such as 'charters' and 'covenants', which have been employed elsewhere in the past in attempts to respond to similar crises. The terminology and its connotations are designed to imbue global agreements with a distinct higher-order character that imposes not only legal but also moral obligations on states, while announcing sweeping, ethically driven paradigmatic changes in a way that pacts, covenants and charters typically do. ${ }^{76}$ One example is the UN Charter of 1945, which quite literally introduced a new world order. Others are the Pact of Bogotá of 1948 (officially known as the American Treaty on Pacific Settlement $)^{77}$ aimed at the peaceful settlement of disputes in the Pacific region, the ICCPR, the ICESCR, and the WCN.

That said, the use of 'environment' in the Pact's name is unfortunate because the term 'environment' has the potential to relegate non-human entities to an objectified, purely utilitarian and commodified status, exclusively there for human use and survival, which consequently also serves as the only reason to protect non-human life. ${ }^{78}$ Underlying the prevailing anthropocentric approach in IEL, 'environment' is a term that is central to other framework-type instruments such as the Rio and Stockholm Declarations, both of which have been unsuccessful in judicially extending ecocentric ethics of care to the non-human world. While I do not suggest that these

74 Le Club de Juristes, n. 72 above, p. 23.

75 Ibid., p. 8.

76 This is aptly illustrated by the insistence of the US on not designating the Rio Declaration on Environment and Development during its negotiation phase as a charter, but merely as a declaration, believing that 'the name "Charter" raised unrealistic expectations about the document's legal content': J. Kovar, 'A Short Guide to the Rio Declaration' (1993) 4 Colorado Journal of International Environmental Law and Policy, pp. 119-40, at 123. See also R. Engel, 'A Covenant Model for Global Ethics' (2004) 8(1) Worldviews, pp. 29-46.

77 Bogotá (Colombia), 30 Apr. 1948, in force 6 May 1949, available at: https://treaties.un.org/doc/Publication/UNTS/Volume\%2030/volume-30-I-449-English.pdf.

78 As Grear says, "the etymology of the term "environment" points relentlessly to an underlying conceptualization of "the environment" as object surrounding an assumed, privileged (and frequently invisibilized) pivot point [namely, the human]': A. Grear, 'Foregrounding Vulnerability: Materiality's Porous Affectability as a Methodological Platform', in A. Philippopoulos-Mihalopoulos \& V. Brooks (eds), Research Methods in Environmental Law (Edward Elgar, 2017), pp. 1-28, at 4. 
instruments have been unsuccessful solely because of their reference to 'environment', the use of words such as 'nature' or 'Earth', as employed in the WCN and the Earth Charter of $2000,{ }^{79}$ impart an altogether more solemn sense of sacredness and inclusiveness of humans as part of the Earth system. Referencing 'nature' or 'Mother Earth' in its name would have aligned better with emerging high-level global political and diplomatic trends, which are moving slowly towards a paradigm focused on Earth system care, such as the recent UNGA initiative to promote 'life in harmony with nature'. 80

Turning to its provisions, the Pact commences encouragingly enough in its Preamble by reaffirming the principles of, among other instruments, the ecocentrically inclined Earth Charter, and by '[a]cknowledging the growing threats to the environment and the need to act in an ambitious and concerted manner at the global level to better ensure its protection'. It then restates the obligations of states in terms of the human development-oriented Sustainable Development Goals, ${ }^{81}$ thereby underlining the centrality of sustainable development as a focal point of its orientation. It embraces a form of mixed weak and strong sustainable development that in trite anthropocentric terms 'allows each generation to satisfy its needs without compromising the capability of future generation [sic] to meet theirs, while respecting [in stronger ecocentric terms] the balance and integrity of the Earth's ecosystem'. The Pact highlights the 'urgency to tackle climate change' and the need to ensure that 'ecosystems are resilient', so that they can 'continue to provide essential services, thereby preserving the diversity of life on Earth, and contribute to human well-being and the eradication of poverty'. ${ }^{82}$ Aside from its recognition of the need to protect ecosystem integrity and some related provisions outlined below, there is very little in the Pact that provides specifically for non-human life protection, justice and integrity.

Immediately following its Preamble is the right to an ecologically sound environment, which is expressed as follows: 'Every person has the right to live in an ecologically sound environment adequate for their health, well-being, dignity, culture and fulfilment'. ${ }^{83}$ Its inclusion at the very start of the Pact's substantive provisions is important, as it confirms the significant weight attributed to it, the fact that this would be the first global treaty to recognize such a right, and even its centrality as a potential Grundnorm of the Pact itself and possibly of global environmental law and governance. The formulation of this right is clearly in line with other examples of the right to a healthy environment found in many domestic constitutions and in regional human rights instruments. ${ }^{84}$ Its objective is to promote

79 N. 19 above.

80 UNGA Resolution 64/196, n. 4 above.

81 UNGA Resolution 70/1 (25 Sept. 2015), 'Transforming our World: The 2030 Agenda for Sustainable Development', UN Doc. A/RES/70/1. For a recent comprehensive overview see D. French \& L. Kotzé (eds), Sustainable Development Goals: Law, Theory and Implementation (Edward Elgar, 2018).

82 Emphasis added.

83 Global Pact, n. 6 above, Art. 1.

84 R. O’Gorman, 'Environmental Constitutionalism: A Comparative Study' (2017) 6(3) Transnational Environmental Law, pp. 435-62; J. May \& E. Daly, Global Environmental Constitutionalism (Cambridge University Press, 2014). 
an ecologically sound environment for the benefit of the human development project and not for the sake of the environment itself. It is a far cry from the rights of nature provisions found in Bolivian and Ecuadorian laws. ${ }^{85}$

The Pact then provides in Article 2 for a fairly wide and thoroughgoing duty of care:

Every State or international institution, every person, natural or legal, public or private, has the duty to take care of the environment. To this end, everyone contributes at their own levels to the conservation, protection and restoration of the integrity of the Earth's ecosystem. ${ }^{86}$

This is a comprehensive formulation establishing an all-embracing duty that is potentially applicable to a wide range of state and non-state entities; an innovative provision which, I would suggest, could expand the application of the Pact horizontally to non-state entities such as transnational corporations. While this provision has the added benefit of potentially empowering global civil society as increasingly critical actors in global environmental governance, the duty's focus on Earth system integrity is also novel and potentially groundbreaking to the extent that it takes an integrated systems approach while referencing the need for the integrity of this system to be maintained.

Article 3 reaffirms the centrality of and critical need for 'sustainable development', and the related Article 4 sets out the duty to observe and ensure inter-generational equity. It is unclear why the drafters of the Pact chose to ignore the critical issue of intra-generational equity at a time of stark inequality between people on Earth, inequality that is usefully expressed through the North-South divide. ${ }^{87}$ Related to the decision not to include a rights of nature provision in the Pact, the issue of intraspecies equity has also been ignored, which is surprising considering that many pervasive climate and broader environmental injustices abound not only between humans of this and the next generation, but also between human and non-human entities of this and the next generation. The Pact's view of equity is therefore decidedly narrow and exclusionary.

Articles 5 to 8 in broad terms repeat, without much effort to revise or 'update' them, traditional IEL principles that one also finds in numerous soft law instruments and MEAs, including the principles of prevention (with the corresponding and well-established obligation to undertake an environmental impact assessment), precaution, the remediation of environmental damage, and the polluter pays principle. They seem simply to have been 'copied and pasted' while no apparent thought was given to reframing them in terms of emerging case law, realities or

85 L. Kotzé \& P. Villavicencio Calzadilla, 'Somewhere between Rhetoric and Reality: Environmental Constitutionalism and the Rights of Nature in Ecuador' (2017) 6(3) Transnational Environmental Law, pp. 401-33; P. Villavicencio Calzadilla \& L. Kotzé, 'Living in Harmony with Nature? A Critical Appraisal of the Rights of Mother Earth in Bolivia' (2018) 7(3) Transnational Environmental Law, pp. 397-424.

86 Global Pact, n. 6 above, Art. 2.

87 C. Gonzales, 'Global Justice in the Anthropocene', in Kotzé, n. 10 above, pp. 219-40. 
progressive moves forward. They are neither innovative nor sufficiently radical to represent anything markedly different from that already offered by IEL.

Articles 9 to 11 provide for the principal tenets of environmental democracy by setting out procedural environment-related rights, which include access to information, public participation, and access to environmental justice. Although it is mainly operative in Europe (but open to ratification to any state party outside Europe), the Convention on Access to Information, Public Participation and Access to Justice in Environmental Matters of 1998 (Aarhus Convention), through its considerably detailed provisions and its institutional compliance machinery, already comprehensively and, some would say, successfully governs these matters. ${ }^{88}$ The Pact does not provide a clause to clarify its relationship with the Aarhus Convention and it remains to be seen how the successes of the Convention will be capitalized on, if at all. Moreover, unlike the Aarhus Convention, the Global Pact does not provide for a compliance mechanism to address complaints of rights infringement. In the case of the Aarhus Convention this is a unique innovation in IEL, which allows members of the public to communicate grievances about a party's compliance directly to a board of independent experts, which can then make recommendations to the Meeting of the Parties. ${ }^{89}$ The procedural rights set out in the Pact therefore provide only general obligations of observance and realization, but the implementation of the obligations these rights impose is left solely to the discretion of states, with no apparent directives applying to states to ensure compliance. In this sense, simply measured against what already exists in IEL, the procedural environmental rights enunciated in the Pact are nothing but hortatory in effect.

While Articles 12 and 13 provide for education and training and research and innovation respectively, Article 14 is more innovative and extends the relevance, if not the application, of the Pact beyond the usual state actors. It provides that states 'shall take the necessary measures to encourage the implementation of this Pact by non-State actors and subnational entities, including civil society, economic actors, cities and regions taking into account their vital role in the protection of the environment'. 90 This provision is broadly similar to the non-state actor application of the duty of care provided in Article 2.

Potentially, the most innovative provisions of the Pact are, firstly, Article 15, which provides that states must adopt effective environmental laws. There is no indication of what effective laws would entail in the text of the Pact itself, but it could possibly relate to normative effectiveness - namely, adherence to a specific minimum standard, which arguably should be informed by sound science. Relatedly, Article 16 places an obligation on states to increase the resilience of people and ecosystems, while

88 Aarhus (Denmark), 25 June 1998, in force 30 Oct. 2001, available at: https://www.unece.org/fileadmin/ DAM/env/pp/documents/cep43e.pdf. See E. Hey, 'The Interaction between Human Rights and the Environment in the European "Aarhus Space”, in A. Grear \& L. Kotzé (eds), Research Handbook on Human Rights and the Environment (Edward Elgar, 2015), pp. 353-76.

89 UN Economic Commission for Europe, 'Guidance Document on the Aarhus Convention Compliance Mechanism', available at: https://www.unece.org/fileadmin/DAM/env/pp/compliance/CC_GuidanceDocument.pdf.

90 Emphasis added. 
Article 17 requires that 'Parties and their sub-national entities refrain from allowing activities or adopting norms that have the effect of reducing the global level of environmental protection guaranteed by current law'. All these provisions could be useful in arguing for the determination of a minimum threshold of Earth system protection that must be effective, must ensure resilience, and cannot be deviated from. However, the Pact does not define this minimum threshold. One possibility could have been to determine the threshold with reference to the planetary boundaries threshold theory. This theory is based on 'a sound scientific knowledge base that has been developed over the past several decades'; ${ }^{91}$ it determines a safe operating space for humanity within a compromised Earth system, while offering a concrete vision of the limitations of the planet (expressed as boundaries) to sustain all human and nonhuman life in the wake of increasing anthropogenic pressures. ${ }^{92}$

The remainder of the Pact deals, in fairly rote terms, with the usual issues of cooperation, armed conflict, the principle of common but differentiated responsibilities and respective capabilities in light of different national circumstances, monitoring and implementation, secretarial arrangements, and so forth. ${ }^{93}$

The Global Pact presents an important opportunity that could offer a radically different alternative for a globally binding constitution-type instrument aimed at overcoming many of the failures of IEL while confronting some of the Anthropocene's socio-ecological challenges. Disappointingly, however, apart from a few novel provisions outlined above, the Pact brings little new to the table. A plain reading of the text confirms that the Pact often regurgitates generally accepted principles of IEL and it is mostly devoid of an ecocentric ethic of socio-ecological care. As it stands, the Pact is not nearly as radical as it could or should have been to serve as an ethically based higher-order global 'constitutional' text, which binds states to clear obligations and which could address the socio-ecological crisis of the Anthropocene. Other commentators, such as Biniaz, have come to a similar conclusion: 'There is a legitimate question whether ... [the Pact] would add value or might, in fact, end up simply creating legal confusion and negatively affecting existing legal regimes'. ${ }^{94}$

Fortunately, with its negotiation process now formally having commenced in the UNGA, there is still an opportunity to revise its content so that it more comprehensively provides for radical measures aimed at protecting Earth system integrity. For reasons detailed below, I argue that the WCN provides a useful bestcase example of the types of provision the Global Pact should include. The Charter could therefore usefully inform the continuing drafting process of the Pact.

91 Kim \& Bosselmann, n. 13 above, p. 289.

92 J. Rockström et al., 'Planetary Boundaries: Exploring the Safe Operating Space for Humanity' (2009) 14(2) Ecology and Society, pp. 1-33.

93 Global Pact, n. 6 above, Arts 18-26.

94 S. Biniaz, "10 Questions to Ask about the Proposed "Global Pact for the Environment"', Aug. 2017, Sabin Centre for Climate Change Law, p. 11, available at: http://columbiaclimatelaw.com/files/2017/08/Biniaz-2017-08-Global-Pact-for-the-Environment.pdf. 


\subsection{World Charter for Nature}

Following on from the Stockholm Declaration on the Human Environment of 1972 and inspired by the publication of the International Union for Conservation of Nature (IUCN)-driven World Conservation Strategy in $1980,{ }^{95}$ the WCN was adopted by majority vote of the UNGA in 1982 (111 votes in favour, 18 abstentions, and one dissenting vote - that of the United States). ${ }^{96}$ The WCN is an 'avowedly ecological instrument, which emphasises the protection of nature as an end in itself'. 97 This much is already evident from its title, which employs the altogether more ecologically inclined notion of 'nature' instead of the predominantly utilitarian term 'environment' that one finds in other global environmental declarations and in the Global Pact. Also, the fact that the WCN was proclaimed 'for nature' implies that it was done for nature's benefit and not solely to advance the type of utilitarian human objectives that other instruments pursue in defence of promoting the 'human environment' and reconciling 'environment and development' for 'sustainable development'. ${ }^{98}$ More closely resembling the Earth Charter in content instead, it contains 'significant deep ecology statements', 99 and is premised on the idea that human development is possible only if ecological limits are respected, with the notion of safeguarding ecological integrity at the core of virtually all of its provisions.

The Preamble to the WCN acknowledges that benefits from nature depend 'on the maintenance of natural processes and on the diversity of life forms'. It also recognizes 'the crucial importance attached by the international community to the promotion and development of co-operation aimed at protecting and safeguarding the balance and quality of nature'. The permanent sovereign rights of states are acknowledged, but the Preamble emphasizes that states must 'conduct their activities in recognition of the supreme importance of protecting natural systems, maintaining the balance and quality of nature and conserving natural resources, in the interests of present and future generations'. ${ }^{100}$ Although it is not explicitly clear from this wording, terminology such as 'supreme importance' arguably suggests a hierarchy following which permanent sovereignty over natural resources (a notion which has been deeply ingrained in the international law and political order by IEL) should be secondary to the need to ensure ecological integrity.

In an attempt to overcome the Cartesian dualism that pervades virtually all of IEL, the Preamble recognizes that ' $[\mathrm{m}]$ ankind is a part of nature and life depends on the uninterrupted functioning of natural systems', and that '[c]ivilization is rooted

95 IUCN, 'World Conservation Strategy', 1980, available at: https://portals.iucn.org/library/efiles/documents/wcs-004.pdf.

96 UNGA Resolution 37/7, n. 5 above.

97 Sands \& Peel, n. 38 above, p. 37.

98 See the Stockholm Declaration on the Human Environment (n. 73 above), the Rio Declaration on Environment and Development (n. 73 above), and the Johannesburg Declaration on Sustainable Development (UN World Summit on Sustainable Development, Johannesburg (South Africa), 4 Sept. 2002, UN Doc No. A/CONF.199/20, available at: http://www.un-documents.net/jburgdec.htm) respectively.

99 Devall, n. 25 above, p. 30.

100 Emphasis added. 
in nature, which has shaped human culture'. It also affirms that '[e]very form of life is unique, warranting respect regardless of its worth to man, and, to accord other organisms such recognition, man must be guided by a moral code of action'. ${ }^{101}$ Such a moral code of action, when considering the bulk of the Charter's provisions, is premised on ecological sustainability. Noting the pervasive destructive consequences of the prevailing economic order and the North-South divide that it engenders, the WCN states that ' $[t]$ he degradation of natural systems owing to excessive consumption and misuse of natural resources, as well as the failure to establish an appropriate economic order among peoples and among States, leads to the breakdown of the economic, social and political framework of civilization'. ${ }^{102}$ This acknowledges that the current economic order is skewed towards consumerism, the exploitation of nature for the benefit of the few, while it recognizes the significant role that an ecologically intact Earth system plays in achieving North-South justice and maintaining peace, stability and social order. Such an acknowledgement further reaffirms the need to keep the Earth system intact and functioning optimally for all other systems to function. To this end, the WCN could be said to embrace the importance of a holistic systems approach to ensuring Earth system integrity, an approach which aligns with emerging Anthropocenefocused analytical frameworks such as planetary boundaries and Earth system governance. $^{103}$

Following its preambular provisions, the Charter provides several general principles. These include, among others: 'Nature shall be respected and its essential processes shall not be impaired'; ${ }^{104}$ ' $[\mathrm{t}]$ he genetic viability on the earth shall not be compromised; the population levels of all life forms, wild and domesticated, must be at least sufficient for their survival'; ${ }^{105}$ and '[e]cosystems and organisms, as well as the land, marine and atmospheric resources that are utilized by man, shall be managed to achieve and maintain optimum sustainable productivity, but not in such a way as to endanger the integrity of those other ecosystems or species with which they coexist'. 106

These principles respectively embrace the notions of respect and responsibility for nature, the need to observe Earth system limits and planetary boundaries, and the need to preserve Earth system integrity, arguably marking a " "paradigm shift in environmental law" to biocentrism' ${ }^{107}$ It is significant in this context that the Charter

\footnotetext{
101 Some commentators, however, might correctly argue that references to 'man' are an unfortunate turn of phrase that serves only to strengthen an exclusionary, exploitative and repressive masculinist ontology that is typical of Cartesian dualism: A. Grear, 'The Vulnerable Living Order: Human Rights and the Environment in a Critical and Philosophical Perspective' (2011) 2(1) Journal of Human Rights and the Environment, pp. 23-44.

102 Emphasis added.

103 F. Biermann, Earth System Governance: World Politics in the Anthropocene (The MIT Press, 2014). 104 UNGA Resolution 37/7, n. 5 above, Art. 1.

105 Ibid., Art. 2.

106 Ibid., Art. 4.

107 J. Bruckerhoff, 'Giving Nature Constitutional Protection: A Less Anthropocentric Interpretation of Environmental Rights’ (2008) 86 Texas Law Review, pp. 615-46, at 618.
} 
was initiated and driven by Global Southern countries in the UNGA (notably with the support of the IUCN). ${ }^{108}$ Consequently, the WCN leans towards the types of principle that actively seek to counter the prevailing Western, Eurocentric and anthropocentric neoliberal development ethic that global Northern countries are generally seen to pursue. Yet, this did not discourage most developed Northern countries from supporting the Charter, which indicates a willingness to accommodate concerns relating to the North-South divide. ${ }^{109}$

The 'Functions' section of the Charter provides for controls on and the limitation of economic development. It states, for instance: 'In the decision-making process it shall be recognized that man's needs can be met only by ensuring the proper functioning of natural systems';10 '[i]n formulating long-term plans for economic development, population growth and the improvement of standards of living, due account shall be taken of the long-term capacity of natural systems to ensure the subsistence and settlement of the populations concerned'; ${ }^{111}$ and '[l]iving resources shall not be utilized in excess of their natural capacity for regeneration'. ${ }^{112}$ As is the case with the principles of the Charter, these provisions are temporally geared towards the future and collectively aim to allow for some human development, but with due recognition that such development can occur only within Earth system limits.

In its final part, titled 'Implementation', the Charter directs states to implement several types of activity to achieve its objectives. Of particular importance for present purposes is Article 14, which provides that '[t]he principles set forth in the present Charter shall be reflected in the law and practice of each State, as well as at the international level'. Article 21 broadens this obligation by applying it also to nonstate entities, and implores public authorities, international organizations, individuals, groups and corporations to '[i]mplement the applicable international legal provisions for the conservation of nature and the protection of the environment'. These provisions collectively acknowledge the importance of bringing domestic, regional and international law regimes in line with the provisions of the Charter and to use these regimes to achieve the objectives of the Charter. The provisions further innovatively extend potential obligations incurred under the WCN to non-state parties as well.

In sum, more than any other existing instrument of IEL, the WCN arguably most fully represents the idea of global environmental constitutionalism. This is borne out by several of the points raised in the preceding analysis of its key provisions. In addition, the Charter has been described as 'special in nature'. ${ }^{113}$ It is 'special'

108 The Charter was initiated during the Twelfth General Assembly of the IUCN in Kinshasa (Zaire) in 1975 through an address to the Assembly by Mobutu Sese Seko. For a detailed discussion see W. Burhenne \& W. Irwin, Beiträge zur Umweltgestaltung: The WCN: Legislative History (Erich Schmidt Verlag, 1986), pp. 14-39.

109 Gonzales, n. 87 above.

110 UNGA Resolution 37/7, n. 5 above, Art. 6.

111 Ibid., Art. 8.

112 Ibid., Art. 10(a).

113 V. Koester, 'From Stockholm to Brundtland' (1990) 20(1-2) Environmental Policy and Law, pp. 14-9, at 15 . 
because it was not only adopted but also solemnly 'proclaimed' in the same way that the UDHR was. It contains strong ethical principles of a very broad nature that underline a systems approach, principles that are comprehensive, and that seek to counter the prevailing sectoral approach of IEL. ${ }^{114}$ It is aimed at state and non-state parties, including individuals, thus signalling a traditional vertical, and an innovative horizontal application that one does not often encounter in IEL (what is also known as 'third party effect' or Drittwirkung in domestic constitutional terms). ${ }^{115}$ The Charter also employs the obligatory form 'shall' instead of the exhortatory 'should', a choice which engenders an altogether more deliberate sense of obligation. ${ }^{116}$ While in some instances it reiterates existing principles of IEL, it elaborates and supplements these where necessary, thus reinforcing the belief that the Charter not only 'represents a codification of the fundamental rules which should be applied in order to achieve the conservation of nature', but also 'highlights the lacunae' which exist in IEL. 117

Yet, in the same way that constitutions are framework texts setting out general provisions, the WCN does not contain detailed rules. It has been crafted in a way that would allow for its principles to be 'developed, materialized and adapted according to circumstances and to problems requiring regulation or other response at the global, regional, national and local levels'. ${ }^{118}$ Sceptics might well argue that the Charter does not provide for any rights-based provisions which, as indicated above, are usually central elements of global environmental constitutionalism; but even without these, its provisions collectively aim to achieve what such rights provisions typically endeavour to accomplish anyway - namely, a strong sense of ecological obligation and a high level of protection:

A first attempt to free nature from human arbitrariness is represented in the 'World Charter for Nature', ... Although this charter does not go so far as to grant nature its own rights and to acknowledge nature as a legal subject, it does attempt to move beyond the anthropocentric and narrowly egocentric perspective of the modern world which sees nature to be there only for humans. ${ }^{119}$

In sum, as Mackey says, the Charter 'reflects a strong sense of ecological integrity and remains an historic landmark in the evolution of global ethics'. ${ }^{120}$

\footnotetext{
114 Commentators have correctly indicated that some of the Charter's principles, such as the precautionary principle, are among the " strongest" formulations' that exist, and that 'the [precautionary] principle can be interpreted as calling for absolute proof of safety before allowing new technologies to be adopted': K. Foster, P. Vecchia \& M. Repacholi, 'Science and the Precautionary Principle' (2000) 288(5468) Science, pp. 979-81, at 979.

115 See, among others, E. Engle, 'Third Party Effect of Fundamental Rights (Drittwirkung)' (2009) 5(2) Hanse Law Review, pp. 165-73.

116 Koester, n. 113 above, p. 15.

117 Burhenne \& Irwin, n. 108 above, p. 128.

118 Ibid.

119 J. Moltmann, 'Reconciliation with Nature' (1991) 11(2) Word and World, pp. 117-23, at 121.

120 B. Mackey, 'The Earth Charter and Ecological Integrity: Some Policy Implications' (2004) 8(1) World Views, pp. 76-92, at 85 .
} 


\section{CONCLUSION}

Admittedly, a desire for positive change might be seen to interfere with a more realistic assessment of the potential of a constitutionalized form of IEL to contribute to efforts that must address the Anthropocene's socio-ecological crisis. After all, we live in a deeply fractured world that is haunted by unpredictable (and in certain instances potentially devastating) political and economic forces, such as those explicated by Trump, Putin, North Korea, and Brexit. Neoliberalism and its exploitative destruction are also deeply entrenched in our socio-economic systems, while the privileged and politically powerful elite seems intent on maintaining the status quo at the cost of a vulnerable living order.

Clearly, humanity stands at the precipice of deciding the future of life on Earth; a precipice that is symbolized by the Anthropocene, which usefully highlights humanity as a devastating geophysical force that is negatively impacting upon Earth system integrity. However, the Anthropocene's imagery also highlights the critical need for a radical transformation of IEL and global environmental governance which, I believe, could happen along the lines of a constitutional approach to global socio-ecological care. It is, after all, now sufficiently clear that 'the processes of convergence between Holocene and Anthropocene conditions will require response or transformation, including the development of new legal axioms, in accordance with the needs of the new situation'. ${ }^{121}$

It is significant that the Global Pact has already reached a critically important stage in the UN processes where states have indicated their willingness to negotiate, and hopefully to adopt in the near future this instrument as the cornerstone of IEL. Acting as a binding global environmental constitution (or a 'new legal axiom'), the Global Pact has considerable potential to respond to the socio-ecological crisis of the Anthropocene and to capitalize on the momentum of the global environmental constitutional moment this new epoch announces. In its present form, however, the Pact disappoints by failing to provide the type of innovative and radical transformational provisions that the Anthropocene demands. Apart from a few exceptions, it mostly rehashes trite principles found in several other instruments of IEL, and the majority of its provisions are not sufficiently geared towards countering the neoliberal growth-without-limits culture that permeates society, its laws, politics and socio-economic processes. The Global Pact is therefore unable in its present form to be a global environmental constitution for the purpose of the Anthropocene, and unless thoroughly revised, it will be a dead letter. While other ecocentric instruments, such as the Earth Charter, could play ancillary roles in guiding the Pact's development, its revision could, and I would suggest should, also be informed by the WCN, which - while relegated to the periphery of state concern - could be given a second lease on life through the incorporation of its radical provisions in the final text of the Global Pact.

121 Vidas et al., n. 28 above, p. 11. 